\title{
The Role of Insurers in Promoting Adaptation to the Impacts of Climate Change
}

\author{
Robert E.T. Ward, Celine Herweijer, Nicola Patmore and \\ Robert Muir-Wood \\ Risk Management Solutions, Peninsular House, 30 Monument Street, London EC3R 8NB, U.K. \\ E-mail: bob.ward@rms.com
}

Scientific evidence is accumulating that climate change is having an impact on the frequency, intensity and geographical distribution of extreme weather events. With these trends likely to continue for the foreseeable future, the insurance industry can help society to adapt, by limiting and managing risks associated with extreme weather, and thereby maintaining the insurability of potentially vulnerable and exposed populations. There are already examples of the insurance industry promoting efforts to mitigate the impacts of weather hazards, by disseminating information about reducing the vulnerability of properties, offering financial incentives to invest in mitigating the impacts of extreme weather, and by working in partnership with policy-makers to establish maximum thresholds of acceptable risk. However, these efforts need to be more widely promoted by insurers to make a significant contribution to society's adaptation to climate change.

The Geneva Papers (2008) 33, 133-139. doi:10.1057/palgrave.gpp.2510153

Keywords: insurance; climate change; weather; adaptation; mitigation

\section{Introduction}

One of the main ways in which human populations currently cope with the risks of extreme weather-related hazards, such as windstorms and flooding, is through insurance. It allows policy-holders to pursue their daily lives safe in the knowledge that if they are adversely affected by an unexpected extreme event, they will be provided with financial support and assistance to recover from their losses. In this way, insurance underpins sustainable economic activity, by sharing and spreading the risk of financial losses across society, and reducing the potential consequences for individuals.

But this system only works if insurers can adequately quantify the risks to policyholders of extreme weather-related events. The risk to any individual's life, property or possessions consists of three main components: the probability of a particular weather hazard, the exposure and vulnerability to that hazard, and the potential cost of being affected by that hazard. Changes to any three of these components can cause the risk to an individual to rise or fall.

There is evidence that the risks posed by extreme weather-related hazards have been increasing over the past few decades, as illustrated by figures of rising global insured 
losses from natural catastrophes. ${ }^{1}$ After accounting for changes in population and wealth, it has been shown that changes in extreme weather events may be responsible for a growth in losses by about 2 per cent a year since the 1970 s. $^{2}$

This finding is consistent with mounting scientific evidence that the frequency, intensity and geographical distribution of some weather hazards are changing as a result of rising atmospheric concentrations of greenhouse gases. These trends are expected to continue as the world warms, leading to, for example, more intense heatwaves, heavy rainfall events, droughts and tropical cyclones. The most authoritative review of the research on climate change has concluded that even if efforts to stabilise atmospheric concentrations of greenhouse gases are successful in the next few decades, changes in extreme weather are likely to continue for the foreseeable future. ${ }^{3}$

However, it is also clear that changes in weather-related hazards are not the only factors responsible for the patterns of increased risk and losses. Growing numbers of people, businesses and properties are being located in areas that are exposed to extreme weather-related hazards. And while successful efforts are being made to reduce vulnerabilities to these hazards, for example through more robust buildings, the overall effect is that the size of the global population at risk from extreme weather is increasing.

The insurance industry can act to tackle these hazard trends by playing its part in climate change mitigation, through the promotion of ways to reduce greenhouse gas emissions, for instance, in the form of coverage for renewable energy infrastructure. But insurers are also well placed to help society to adapt to the impacts of climate change, by promoting the effective limitation and management of risks from extreme weather-related hazards. ${ }^{4}$

Despite the opportunity and need for the insurance industry to play a leading role in society's adaptation to climate change impacts, it appears that it is receiving less attention from companies than measures to mitigate through reducing greenhouse gas emissions. Of 25 types of activity undertaken by private insurers that were identified in a recent survey, fewer than a quarter focused on adaptation rather than mitigation. ${ }^{5}$

However, there are some good examples of how insurers can promote adaptation, primarily through measures to maintain the insurability of properties. Three examples are highlighted here, covering the provision of information about reducing the vulnerability of properties, financial incentives to invest in mitigating impacts of extreme weather and partnerships with policy-makers to establish maximum thresholds of acceptable risk.

\section{Provision of Information about Reducing the Vulnerability of Properties}

The Institute for Business and Home Safety (IBHS) was established in 1976 by insurance and reinsurance companies in the United States as a non-profit initiative "to

\footnotetext{
${ }^{1}$ Munich Re Group (2007).

${ }^{2}$ Muir-Wood et al. (2006).

${ }^{3}$ Intergovernmental Panel on Climate Change (2007).

${ }^{4}$ Wilbanks et al. (2007).

${ }^{5}$ Mills and Lecomte (2006).
} 
reduce the social and economic effects of natural disasters and other property losses by conducting research and advocating improved construction, maintenance and preparation practices", 6

In 2004, IBHS published a Californian edition of its leaflet on "Protect your home against wildfire damage", 7 following record losses in southern California during the previous year. Aimed at home-owners, it provided advice about making properties more likely to survive wildfire, including guidance on how to create a "defensible space" within which the risk of fire is reduced by pruning or removing combustible vegetation. It also gave information about building and retro-fitting homes with non-flammable materials. The outlined actions ranged from those that could be carried out by home-owners themselves, to those requiring professional services.

The leaflet has been distributed to properties in key locations in California and was published on the website of IBHS. However, no analysis has been published of its effectiveness. Furthermore, it does not mention potential changes in wildfire hazard in California due to climate change. Under a medium-high scenario for greenhouse gas emissions, it has been estimated that the wildfire risk in California could increase by as much as 35 per cent by the middle of the 21 st century, and up to 55 per cent by its end. ${ }^{8}$ The average annual cost of damage caused by wildfires is projected to increase by about 30 per cent as a result.

\section{Financial Incentives to Invest in Mitigating Impacts of Extreme Weather}

Following the devastation of Hurricane Andrew in 1992, the Florida legislature introduced Statute 627.029 requiring insurance companies in the State from 1 July 1994 on to file rates for residential property that included "appropriate discounts, credits, or other rate differentials, or appropriate reductions in deductibles, for properties on which fixtures actuarially demonstrated to reduce the amount of loss in a windstorm have been installed". 9 The statute was updated in 2002 to ensure that homes constructed in compliance with the Florida Building Code (FBC) were automatically eligible for the insurance discounts. ${ }^{10}$

No analysis has been published of the costs or benefits for insurers of the provisions introduced under the statute. However, estimates of the impact of replacing the Standard Building Code (SBC) with the FBC in 2002 suggest that losses from wind damage to homes would be reduced by between 26 and 61 per cent, and that homeowners would find that the costs of constructing stronger houses in compliance with the FBC would be outweighed by the potential savings, including the reduction in insurance premiums due to the wind mitigation discounts. ${ }^{11}$ In addition, it has been calculated that the construction of homes in compliance with the SBC and FBC

\footnotetext{
${ }^{6}$ Institute for Business and Home Safety (2007a).

${ }^{7}$ Institute for Business and Home Safety (2004).

${ }^{8}$ Westerling and Bryant (2006).

${ }^{9}$ Florida Legislature (1994).

${ }^{10}$ Florida Legislature (2002).

11 Applied Research Associates (2002).
} 
resulted in a reduction of 60 per cent in the frequency of claims, and a 42 per cent reduction in their average size, arising from Hurricane Charley in August 2004, compared with homes that were built before the codes were adopted. ${ }^{12}$

Despite these benefits, insurance companies in Florida do not appear to have made great efforts to publicise the incentives for home-owners to invest in wind mitigation measures. Concern that few home-owners were aware of the insurance provisions laid down in the Statute led to further legislation requiring insurers since October 2005 to notify those applying for policies of the discounts available. ${ }^{13}$

There is evidence that the proportion of hurricanes in the North Atlantic Basin reaching the highest categories of intensity has been increasing since $1970^{14}$ and that the frequency of hurricanes generally has been higher since $1995 .{ }^{15}$ Both of these trends have been attributed to climate change, although some researchers have disputed these claims. ${ }^{16}$ If both trends continue into the future, there is likely to be an increased risk of windstorm damage to properties in Florida, unless impact mitigating measures, such as those encouraged by Florida Statute 627.0629 , continue to be implemented.

\section{Partnerships with Policy-Makers to Establish Maximum Thresholds of Acceptable Risk}

The U.K. differs from many other European and North American countries in having a private insurance market that, since the 1960s, has offered widely available coverage against flooding. However, the damage caused by flood events and the potential impacts of climate change have prompted significant actions from U.K. insurers and policy-makers.

In autumn 2000, inland flooding occurred in some 700 locations across England and Wales, causing damage to about 10,000 properties and insured losses of $£ 1.3$ billion. Following this flooding, the Association of British Insurers (ABI) warned that properties in some areas were becoming uninsurable against flood risk because of "more frequent and heavy rain; poor maintenance of flood defences; and inadequate investment in protecting properties that have been built in flood risk areas". ${ }^{17}$

Members of the ABI agreed to continue offering flood cover to policy-holders in existing domestic properties and small businesses, save in "exceptional circumstances", but in return called for the U.K. Government to take action on "greater investment in defences; radical curtailment of development in flood risk areas; and faster and more consistent decisions on flood defences".

The government subsequently increased its annual expenditure on flood defences by more than 40 per cent, introduced new guidance to require flood risk to be taken into

\footnotetext{
${ }^{12}$ Institute for Business and Home Safety (2007b).

13 Kaminski (2006).

14 Emanuel (2005).

${ }^{15}$ Mann and Emanuel (2006).

${ }^{16}$ Landsea (2007).

${ }^{17}$ Association of British Insurers (2001).
} 
account during the planning applications for new developments and offered a commitment to improve the decision-making process on defences. ${ }^{18}$

In September 2002, the ABI issued a "Statement of Principles" committing its members to the provision of coverage for properties exposed to an annual probability of flooding below a maximum threshold of 1.3 per cent (i.e. a one-in-75 chance). It noted that about a quarter of properties located on floodplains were exposed to higher risks, but agreed to continue policies for properties that were due to fall below this threshold within 5 years as a result of planned improvements in flood defences. $^{19}$

The Statement of Principles was updated in October $2005 .^{20}$ The commitment to continue providing flood cover was again made dependent on government policies to improve flood defences and to reduce the risk of flooding in other ways, for instance through better planning for new property developments. The government acknowledged that the benefits of a programme of increased expenditure on maintenance and replacement of existing defences, together with new defences, outweigh costs by about six to one. ${ }^{21}$

The ABI has continued to highlight the need for greater investment in flood defences, warning in November 2006 that a rise in sea level of $40 \mathrm{~cm}$ from climate change could increase the number of properties at risk of storm surge flooding along the east coast of England by about 48 per cent. ${ }^{22}$ It recommended that $£ 6.1-8.6$ billion was required to improve defences along the coast.

\section{Conclusions}

Climate change is altering the frequency, intensity and geographical distribution of weather-related hazards. Many people will find that their properties become uninsurable by private companies if increases in weather-related hazard are allowed to translate into higher risks.

History already records the consequences of insurance companies allowing populations to become uninsurable by the private market, as a reaction to changes in weather-related hazards. As the advent of the National Flood Insurance Programme in the United States in the 1960s and the development of statefunded insurance and reinsurance arrangements for dealing with windstorms in Florida in the last decade have demonstrated, the retreat of the private market can result in risks being under-written with public money, or borne by property owners themselves.

Private insurers can help society to adapt to the impacts of climate change by actively promoting insurability against weather-related hazards. They can raise the awareness of policy-holders about measures for reducing the vulnerability of

\footnotetext{
${ }^{18}$ Association of British Insurers (2002a).

19 Association of British Insurers (2002b).

20 Association of British Insurers (2005).

${ }^{21}$ Department for Environment, Food and Rural Affairs (2004).

${ }^{22}$ Association of British Insurers (2006).
} 
properties. They can introduce financial incentives for policy-holders to invest in measures that mitigate the impacts of extreme weather on their properties. And they can enter into partnerships with governments and other policy-makers to ensure that maximum thresholds of acceptable risk are established and maintained.

\section{References}

Applied Research Associates (2002) Development of Loss Relativities for Wind Resistive Features of Residential Structures (Version 2.2), Raleigh, NC, Applied Research Associates, 42pp.

Association of British Insurers (2001) Flooding: A Partnership Approach to Protecting People, Association of British Insurers, London, 9pp.

Association of British Insurers (2002a) Renewing the Partnership - How the Insurance Industry will Work with Others to Improve Protection Against Floods, Association of British Insurers, London, 10pp.

Association of British Insurers (2002b) 'Insurers Announce New Principles for Flood Insurance', News Release 85/02, 26 September 2002, from http://www.abi.org.uk/Newsreleases/viewNewsRelease.asp? nrid $=694$, accessed 17 August 2007.

Association of British Insurers (2005) ABI Statement of Principles on the Provision of Flood Insurance: Updated Version, from http://www.abi.org.uk/BookShop/ResearchReports/Flooding_statementofprinciples 2005.pdf, accessed 17 August 2007.

Association of British Insurers (2006) Coastal Flood Risk - Thinking for Tomorrow, Acting Today: Summary Report, Association of British Insurers, London, 48pp.

Department for Environment, Food and Rural Affairs (2004) National Assessment of Defence Needs and Costs for Flood and Coastal Erosion Management (NADNAC): Summary report, London, 28pp.

Emanuel, K. (2005) 'Increasing destructiveness of tropical cyclones over the past 20 years', Nature 436: 686-688.

Florida Legislature (1994) 'The 1994 Florida statutes', from http://www.leg.state.fl.us/statutes/index.cfm? StatuteYear $=994 \& \mathrm{Tab}=$ statutes $\&$ Submenu $=1$, accessed 21 August 2007.

Florida Legislature (2002) 'The 2002 Florida statutes', from 2002->Ch0627-> Section per cent200629\# 0627.0629" type="URL" > http://www.leg.state.fl.us/statutes/index.cfm?App_mode = Display_Statute $\&$ Search_String $=\& U R L=$ Ch0627/SEC062.HTM\&Title $=$ - > 2002- > Ch0627- > Section per cent200629 \#0627.0629, accessed 21 August 2007.

Institute for Business and Home Safety (2004) 'Protect you home against wildfire: California edition', from http://www.ibhs.org/publications/downloads/478.pdf, accessed 28 August 2007.

Institute for Business and Home Safety (2007a) 2006 Annual report: Stronger together, Institute for Business and Home Safety, Tampa, FL, 18pp.

Institute for Business and Home Safety (2007b) The benefits of modern wind resistant building codes on hurricane claim frequency and severity: A summary report, Institute for Business and Home Safety, Tampa, FL, 6pp.

Intergovernmental Panel on Climate Change (2007) Climate change 2007: The physical science basis. Contribution of Working Group I to the Fourth Assessment Report of the Intergovernmental Panel on Climate Change, Cambridge: Cambridge University Press, 996pp.

Kaminski, J.L. (2006) Hurricane windstorm insurance in Florida, Connecticut Office of Legislative Research, Research Report 2006-R-0498, from http:/www.cga.ct.gov/2006/rpt/2006-r-0498.htm, accessed 17 August 2007.

Landsea, C.W. (2007) 'Counting Atlantic tropical cyclones back to 1900', Eos 88: 197.

Mann, M.E. and Emanuel, K. (2006) 'Atlantic hurricane trends linked to climate change', Eos 87: 233.

Mills, E. and Lecomte, E. (2006) From Risk to Opportunity: How Insurers Can Proactively and Profitably Manage Climate Change, Boston, MA: Ceres, 42pp.

Muir-Wood, R., Miller, S. and Boissonnade, A. (2006) 'The search for trends in a global catalogue of normalized weather-related catastrophe losses', in P. Höppe and R. Pielke (eds) Workshop on Climate Change and Disaster Losses: Understanding and Attributing Trends and Projections, 25-26 May 2006, Munich: Munich Re Hohenkammer, Germany, Munich: Munich Re, pp. 161-167. 
Munich Re Group (2007) Natural Catastrophes 2006: Analyses, Assessments, Positions, Munich: Munich Re, $50 \mathrm{pp}$.

Westerling, A. and Bryant, B. (2006) Climate Change and Wildfire in and Around California: Fire Modeling and Loss Modeling, California Climate Change Center, Sacramento, CA, 28pp.

Wilbanks, T.J., Romero Lankao, P., Bao, M., Berkhout, F., Cairncross, S., Ceron, J.-P., Kapshe, M., Muir-Wood, R. and Zapata-Marti, R. (2007) 'Industry, settlement and society', in M.L. Parry, O.F. Canziani, J.P. Paultikof, P.J. van der Linden and C.E. Hanson (eds) Climate Change 2007: Impacts, Adaptation and Vulnerability. Contribution of Working Group II to the Fourth assessment Report of the Intergovernmental Panel on Climate Change, Cambridge: Cambridge University Press, pp. 357-390.

\section{About the Authors}

Robert E.T. Ward is Director of Global Science Networks at Risk Management Solutions. He joined the company in 2006 after eight years at the Royal Society, the U.K. National Academy of Science, where he was the senior manager for policy communication. Bob has also worked as a freelance science writer and as a reporter for The Daily Telegraph newspaper. He has a B.Sc. in Geology.

Dr. Celine Herweijer is the Principal Scientist, Future Climate, at Risk Management Solutions. She leads the company's climate change agenda, directing new modeling work on climate change risk assessment. Celine was previously Project Manager of the Lighthill Risk Network and worked in the Water Branch at the United Nations in New York. Celine holds a Ph.D. in Climate Modeling from Columbia University.

Dr. Nicola Patmore is the Senior Research Analyst for climate change at Risk Management Solutions. She was previously a Scientific Advisor on climate change for the U.K. Government, and as a Policy Analyst on the Stern Review on the Economics of Climate Change. Nicola holds a PhD in Atmospheric Physics from Imperial College London, and a degree in Physics from the University of Warwick.

Dr. Robert Muir-Wood is Chief Research Officer at Risk Management Solutions. He was lead author covering Climate Change, Insurance and the Finance for the Fourth Assessment Report of the Intergovernmental Panel on Climate Change, published in 2007. He holds an M.A. and Ph.D. from Cambridge University and has had more than 20 years experience in the probabilistic modelling of natural catastrophe risk. 